\title{
Potential of Locally Available Clay as Raw Material for Traditional-Ceramic Manufacturing Industries
}

\author{
Adnan Mousharraf ${ }^{1}$, Md. Sazzad Hossain , Md. Fakhrul Islam ${ }^{2}$ \\ 1 Department of Materials and Metallurgical Engineering, BUET \\ 2 Department of Glass and Ceramic Engineering, BUET
}

\begin{abstract}
The traditional white-ware manufacturing industries in Bangladesh use clay as the prime raw material which is mostly imported from abroad. The main reasons are the lack of proper clay refining technolo gy in the country and in some part the unsuitable chemical and structural composition of the locally available naturally occurring clays. Moreover, particle size has also been identified as a major challenge in processing of naturally available clay. These two vital aspects affect plasticity and strength of clay during their processing. The composition and particle size of locally available clay were investigated using X-Ray Fluorescence (XRF) and X-Ray Diffraction $(X R D)$ to reveal the potential of these clays for industrial purpose upon refining. XRF analysis showed presence of excess $\mathrm{SiO}_{2}$ content in the form of Silicate, $\mathrm{Fe}_{2} \mathrm{O}_{3}$ and $\mathrm{TiO}_{2}$; all of which pose a challenge in the refining process. Moreover the amount of $\mathrm{Al}_{2} \mathrm{O}_{3}$ in most of the compositions is also not up to the minimum level. Using the data based on statistics on particle sizes of raw materials of various origins, this experiment was aimed to reveal the composition and properties of locally available clay that can be projected for further refining to make suitable as raw material for whiteware industries.
\end{abstract}

\section{Introduction}

Different Clay is the principal raw material in the traditional-ceramic manufacturing industries. Depending on composition and various other technical characteristics, clay can be processed into different shapes where plasticity, strength and other parameters are varied. The features that industries most frequently look for in clay are mainly the composition and particle size, which determines the feasibility of that clay to be processed. Both these variables are subject to distinction based on the origin of clay.

Geological studies reveal clay to be of two different types based on the way they were deposited. The type of clays which are found to be at the place of their origin is called Residual Clay. Typically these types of clays are deposited along the igneous rocks from which they were formed and are obtained in relatively pure state. Based on their in-situ nature, they are found to have coarse particle size with a wide particle size distribution. Due to this, these clays show lower plasticity. China clay is an example of residual clay, which is highly pure, has larger particle size and lower plasticity. The other type is Sedimentary Clays which are deposited by transportation from their origin by natural agencies like water, wind etc. Sedimentary clays are seldom obtained in pure state, due to impurities that are picked up during transportation and are retained in the deposits. The grinding action of clay particles in water, wind and ice results in very fine particle sizes, giving the sedimentary clay very high plasticity. Ball clay is an example of sedimentary clay, which is not highly pure, but has a finer particle size and very good plastic property.
Geological surveys indicated that Bangladesh has deposits of both Residual and Sedimentary types of clays. A number of places accross the country have been identified as the sources of various types of clay. Notable locations are Bijoypur in Mymensingh, Barapukuria and Maddhyapara in Dinajpur etc. The clays that are availabe in these sources are mainly China Clay, White Clay, Red Clay, Black Clay, Brick Clay etc.

\section{Experimental}

\section{Analysis of Clay Properties}

A number of researches have been carried out so far on clays from various region accross the country in order to identify the compositional variation. Such analysis is usually performed with the X-Ray Fluorescence (XRF) and X-Ray Diffraction (XRD) methods. Table 1 lists the $\mathrm{XRF}$ analysis of some locally available clay types.

In reference to the data in Table 1, a comparison of local clay to imported material (standard compositions) would make obvious that the indigenous material is much higher in $\mathrm{SiO} 2, \mathrm{Fe} 2 \mathrm{O} 3$ and $\mathrm{TiO} 2$ content and falling short in $\mathrm{A} 12 \mathrm{O} 3$ content. Typically, majority of Silic a stay in free form as Quartz. Rest of the Silica content are associated with Alumina in bonded form, which forms phases like Kaolinite, Halloysite etc (Table 3). Moreover, amount of impurities like $\mathrm{Fe} 2 \mathrm{O} 3$ and $\mathrm{TiO} 2$ are also high in most of the local clay types. 
Table 1: XRF analysis of local and imported clay [1]

\begin{tabular}{|c|c|c|c|c|c|}
\hline \multirow{2}{*}{$\begin{array}{c}\text { Compositio } \\
\mathrm{n}(\%)\end{array}$} & \multicolumn{3}{|c|}{$\begin{array}{c}\text { Locally Available } \\
\text { Clay }\end{array}$} & \multicolumn{2}{|c|}{$\begin{array}{c}\text { Standard } \\
\text { Composition }\end{array}$} \\
\hline & $\begin{array}{l}\text { Bijoypur } \\
\text { Clay }\end{array}$ & $\begin{array}{l}\text { Red } \\
\text { Clay }\end{array}$ & $\begin{array}{l}\text { Black } \\
\text { Clay }\end{array}$ & $\begin{array}{l}\text { Ball } \\
\text { Clay }\end{array}$ & $\begin{array}{l}\text { China } \\
\text { clay }\end{array}$ \\
\hline $\mathrm{SiO}_{2}$ & 70.08 & 62.80 & 53.13 & 44.63 & 50.18 \\
\hline $\mathrm{Al}_{2} \mathrm{O}_{3}$ & 27.24 & 20.43 & 23.41 & 36.93 & 33.34 \\
\hline $\mathrm{Fe}_{2} \mathrm{O}_{3}$ & 1.03 & 6.07 & 4.97 & 0.96 & 1.88 \\
\hline $\mathrm{TiO}_{2}$ & 1.65 & 0.99 & 0.98 & 3.57 & 0.01 \\
\hline Others & 0.0 & 10.71 & 18.50 & 13.91 & 14.59 \\
\hline
\end{tabular}

Although Bijoypur Clay (White Clay) has high SiO2 content, but at the same time it has substantial amount of $\mathrm{A} 12 \mathrm{O} 3$ and fairly low impurity content in it. Hence this clay possesses the greatest potential to be turned into industrially suitable raw material for traditional-ceramic manufacturing.

Table 2 shows another XRF analysis, where the compositions of various locally available clay are compared. The data show that $\%$ Silica of the local clay are in the range of $65-73, \%$ Alumina in $22-27, \%$ Iron (III) Oxide in 1-9 and \% Titanium Oxide within $1 \%$, which present the challenges of dealing with local clay for the suitability of industrial application due to high Silica content.

Table 2: XRF analysis of various locally available clays [1]

\begin{tabular}{|c|c|c|c|c|c|}
\hline $\begin{array}{c}\text { Com } \\
\text { positi } \\
\text { on } \\
(\%)\end{array}$ & $\begin{array}{c}\text { Bijoy } \\
\text { pur } \\
\text { Clay }\end{array}$ & $\begin{array}{c}\text { Mymen } \\
\text { singh } \\
\text { Black } \\
\text { Clay }\end{array}$ & $\begin{array}{c}\text { Mym } \\
\text { ensin } \\
\text { gh } \\
\text { Whit } \\
\text { e } \\
\text { Clay }\end{array}$ & $\begin{array}{c}\text { Mymen } \\
\text { singh } \\
\text { White } \\
\text { Yellowi } \\
\text { sh Clay }\end{array}$ & $\begin{array}{c}\text { Mymensi } \\
\text { ngh } \\
\text { Yellowis } \\
\text { h Gray } \\
\text { Clay }\end{array}$ \\
\hline $\mathrm{SiO}_{2}$ & 70.08 & 70.36 & 73.10 & 71.34 & 65.15 \\
\hline $\mathrm{Al}_{2} \mathrm{O}_{3}$ & 27.24 & 24.39 & 22.10 & 24.63 & 23.49 \\
\hline $\mathrm{Fe}_{2} \mathrm{O}_{3}$ & 1.03 & 1.40 & 1.75 & 1.57 & 9.30 \\
\hline $\mathrm{TiO}_{2}$ & 1.65 & 1.44 & 1.11 & 1.44 & 1.28 \\
\hline $\begin{array}{c}\mathrm{Other} \\
\mathrm{s}\end{array}$ & 0.0 & 2.41 & 1.94 & 1.02 & 0.78 \\
\hline
\end{tabular}

Table 3 shows the compositional analysis done by XRD of some locally available clay [1], which strongly indicates the presence of Quartz, in all of them. In general, the presence of excess amount of Quartz lowers the plasticity of the green body and also leads to micro crack formation in the fired body. Moreover, long exposure to silica dust causes significant health hazard.

Table 3: Summary of XRD analysis of local clays [1]

\begin{tabular}{|c|c|}
\hline $\begin{array}{c}\text { Local Clay } \\
\text { Samples }\end{array}$ & $\begin{array}{c}\text { Possible Phases } \\
\text { Present }\end{array}$ \\
Bijoypur Clay & $\begin{array}{c}\text { Kaolinite, Halloysite and } \\
\text { Quartz. }\end{array}$ \\
\hline $\begin{array}{c}\text { Mymensingh Black } \\
\text { Clay }\end{array}$ & $\begin{array}{c}\text { Kaolinite, Quartz and } \\
\text { Biotite. }\end{array}$ \\
\hline $\begin{array}{c}\text { Mymensingh White } \\
\text { Clay }\end{array}$ & $\begin{array}{c}\text { Kaolinite, Halloysite, } \\
\text { Quartz and Phogopite. }\end{array}$ \\
\hline $\begin{array}{c}\text { Mymensingh White } \\
\text { Yellowish Clay }\end{array}$ & $\begin{array}{c}\text { Kaolinite and } \\
\text { Quartz. }\end{array}$ \\
\hline $\begin{array}{c}\text { Mymensingh } \\
\text { Yellowish Gray } \\
\text { Clay }\end{array}$ & $\begin{array}{c}\text { Kaolinite, Palygorskite } \\
\text { and Quartz. }\end{array}$ \\
\hline
\end{tabular}

Figure 1: XRD analysis of China Clay (a) [8], Mymensingh White Clay (b) [1] and Bijoypur Clay (c) [1]

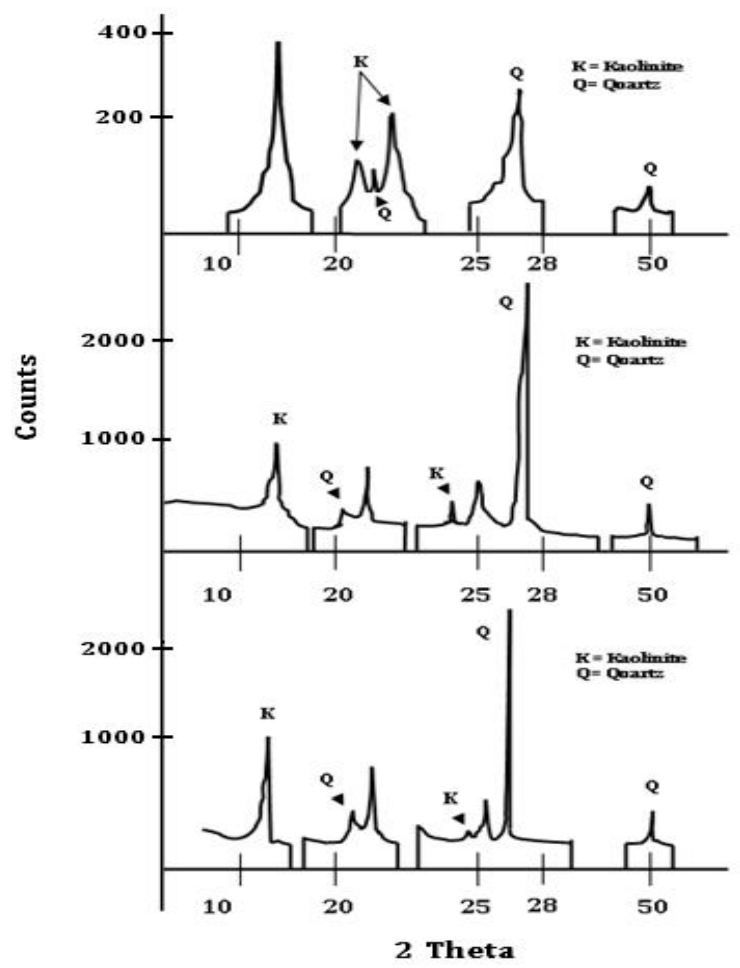


Figure 1 shows the X-Ray Diffraction pattern for three types of clay. Figure 1(a) shows the pattern for standard China Clay and the existence of Quartz and Kaolinite in the composition. Figure 1(b) and 1(c) shows the pattern for locally available Mymensingh White Clay and Bijoypur Clay respectively. The XRD patterns indicate the presence of higher amount of Quartz or free Silica and relatively lower Kaolinite (bonded Silica) content in locally available clay in comparison to those in China Clay. Hence, substantial refining action is necessary to make the indigenous material suitable for industrial manufacturing.

Another important factor for clay to be used as raw material is the particle size. Particle size has a significant role on the plasticity of clay. Generally, the smaller the particle size the better is the plasticity of clay. However, there is a lower limit of particle size below which the property starts to deteriorate. China Clay due to its large particle size shows poor plasticity. Thus, plasticity of green clay body is usually improved by adding other clay like Ball Clay which has very fine particle size. Ideally, the average particle size required for green body mixture is around 45 micron. In case, the mixture has particle size below that, then the green body fails to hold its shape.

Table 4 shows the particle size distribution of local clay which indicates that local clay have larger particle size. Bijoypur Clay, Mymensingh White Clay and Yellowish Gray Clay have particle size larger than 100 micron, whereas Mymensingh Yellowish Gray and Black Clay have particle size just below 100 micron. In general local clays have larger particle size [1].

Table 4: Particle size distribution and analysis of percent residue through siever analyzer [1]

\begin{tabular}{|c|c|c|c|}
\hline \multirow[b]{2}{*}{ Sample } & \multicolumn{3}{|c|}{ Residue \% } \\
\hline & $\begin{array}{l}+140 \\
\text { mesh }\end{array}$ & $\begin{array}{l}+200 \\
\text { mesh }\end{array}$ & $\begin{array}{l}+325 \\
\text { mesh }\end{array}$ \\
\hline Bijoypur Clay & 38.65 & 5.72 & 4.82 \\
\hline $\begin{array}{l}\text { Mymensingh White } \\
\text { Clay }\end{array}$ & 56.47 & 2.57 & 8.32 \\
\hline $\begin{array}{l}\text { Mymensingh White } \\
\text { Yellowish Clay }\end{array}$ & 16.38 & 6.61 & 13.81 \\
\hline $\begin{array}{l}\text { Mymensingh Black } \\
\text { Clay }\end{array}$ & 17 & 5.62 & 9.1 \\
\hline $\begin{array}{l}\text { Mymensingh } \\
\text { Yellowish Gray } \\
\text { Clay }\end{array}$ & 39.05 & 6.66 & 8.13 \\
\hline
\end{tabular}

Table 5 shows the XRF analysis of unwashed and washed Sylhet clay, which indicates that around 5\% silica was removed by sieving. Therefore, for substantial amount of silica removal, other refining processes have to be adopted along with sieving.
Table 5: XRF results of unwashed and washed Sylhet clay [1]

\begin{tabular}{|c|c|c|c|c|c|}
\hline Compound & $\mathrm{SiO}_{2}$ & $\mathrm{Al}_{2} \mathrm{O}_{3}$ & $\mathrm{Fe}_{2} \mathrm{O}_{3}$ & $\mathrm{TiO}_{2}$ & Others \\
\hline $\begin{array}{c}\text { Unwashed } \\
\text { Sylhet } \\
\text { Clay }\end{array}$ & 70.99 & 24.30 & 1.89 & 1.22 & 1.6 \\
\hline $\begin{array}{c}\text { Washed } \\
\text { Sylhet } \\
\text { Clay }\end{array}$ & 65.89 & 26.77 & 2.53 & 1.04 & 3.77 \\
\hline
\end{tabular}

\section{Sources and Possibilities}

The prime raw material of ceramic products is White Clay. The largest deposit of White Clay in Bangladesh was first discovered in 1957 at Bijoypur in Mymensingh which later was discovered to have a significant quantity of China Clay as well [3]. Total reserve of White Clay in this region was estimated to be 2.57 million tons [2] and that of China Clay is more than 40 million tons [4]. However, most of the other sources in Bangladesh are not known to have composition close to that of White or China Clay. In addition, most of locally available clays, except the Bijoypur Clay contain high $\mathrm{Fe} 2 \mathrm{O} 3$ and $\mathrm{TiO} 2$ content (Table 1,2) which precludes their use as industrial raw material.

Since, local clay have large particle size and high level of impurities, about $95 \%$ of raw materials for making quality and exportable ceramic products in Bangladesh are imported from abroad. The main sources are Japan, Germany, New Zealand, South Korea and India [1]. However, the analysis given so far indicates that some of these raw materials have very good potential to be used as quality raw material if the appropriate refining technology is pursued.

\section{Clay Refining Methodology}

On the provision of particle size reduction and proper refining, there is very high potential of developing quality raw materials for present ceramic industries. Currently clay refining is limited to laboratory research and is not practiced on industry scale. Since we have wealth of clay deposit, the potential for clay refining industries in Bangladesh is very high. The process of size reduction and refining of clay on industrial scale requires several stages i.e. slurry formation, sieving, magnetic separation, milling, deflocculation, selective flocculation, clay separation and finally, dewatering of clay.

At first, clay is mixed with pure water to form slurry. Then the slurry is passed through sieves of different mesh size. As Quartz is generally coarser than Kaolinite, a large fraction of Quartz particles get separated from the clay in this process (especially greater than 325 mesh). Then the slurry is passed through a magnetic separator to separate large particles of paramagnetic mineral $\mathrm{Fe} 2 \mathrm{O} 3$. For magnetic separation, a non homogeneous magnetic field is applied and is preferably of average field strength of 1500-15000 gauss. The magnetic field is applied for several hours, so that a sufficient amount of $\mathrm{Fe} 2 \mathrm{O} 3$ can be 
removed [5]. In order to reduce the size of the particles in the slurry, the slurry is then milled for several hours using ball mill or attrition mill. Then suitable deflocculant such as sodium silicate/ sodium condensed phosphate salt is added to the slip and the slurry is continuously agitated. For deflocculation purpose, approximately $3.5-3.75 \mathrm{~kg}$ of sodium silicate is added per ton of clay. When the clay particles become deflocculated, the dispersed clay slip is further diluted to approximately $10 \%$ to $20 \%$ solid content by adding pure water. Thereafter, poly-acrylamide type anionic or nonionic flocculants are added to the slip at a proportion of 3.5-3.75 kg/ton of clay. Before Polyacrylamide addition, $\mathrm{pH}$ should be maintained in the range of 8.0-9.5; for the removal of $\mathrm{TiO} 2$ and the remaining Fe2O3 impurities. At this $\mathrm{pH}$ level, the impurity particles get selectively flocculated with the poly-acrylamide polymer to form heavy flocs; which quickly settle at the bottom and the suspended clay is removed either by gravitational or centrifugal forces. On the other hand, for the removal of fine $\mathrm{SiO} 2$ particles, alkali like ammonium hydroxide should be added at a proportion of $0.5 \mathrm{~kg} / \mathrm{ton}$ of clay; to maintain $\mathrm{pH}$ above 11.5 . At this $\mathrm{pH}$ level, clay particles get selectively flocculated with the polyacrylamide polymer to form heavy flocs and settle at the bottom. The suspended Quartz particles are then removed either by gravitational or centrifugal forces. Finally, the processed clay is dewatered to achieve marketable clays. Rotary drums or hyperbaric pressure filters are usually used for dewatering. In case of filtering, $60 \mathrm{kPa}$ to $150 \mathrm{kPa}$ pressure is applied to remove water from the filter cake. After that the filter cakes are thermally spray dried to reduce the moisture content to desired level [6-7].

\section{Conclusion}

At present, Bangladesh is exporting ceramic tableware in more than 45 countries, including the USA, Italy, Spain, France, New Zealand, Netherlands, Australia and Sweden [1]. Unfortunately, this enormous sector is currently heavily dependent on expensive imported raw materials. Therefore, special attention must be given to extraction and refining technology for the indigenous raw materials, which hopefully will lead the pathway to a substantial socio-economic development.

\section{References}

1. G. Tamjid Chowdhury, "Effect of composition and firing cycle on the properties of high tension ceramic insulator", M. Sc. thesis, MME, BUET, 2004.

2. M. Asaduzzaman, "Mining, Gender and Sustainable Livelihoods", Australian research council, 2008.

3. "The role of a national geological survey in the development of a sustainable society, with special reference to Bangladesh", Geological organization 135 .

4. S.A. Jahan, S. Ahmed and M. Moniruz Zaman, "Studies on the physic-chemical properties of ceramic tiles produced from locally available raw materials", Bangladesh J. Sci. Ind. Res. 43(1), 77-88, 2008.

5. "Method of improving whiteness of clay", US Patents, NO: 3482685.
6. Ramazan Asmatulu, "Removal of the Discoloring Contaminants of East Georgia Kaolin Clay and its Dewatering", Turkish J. Eng. Env. Sci. 26, 447-453, 2002.

7. "Process of purifying clay by selective flocculation", US Patents, NO: 3837482.

8. P. D. Salt, "Quantitative mineralogical analysis of small samples of china clay using $x$ ray diffractometry", British Journal of Industrial Medicine , 42:635-641, 1985 